\title{
Summary of Analysis Results for Sediments Provided by Texas A\&M University
}

\author{
Cynthia Conrado \\ Steven Kreek
}

August 1, 1999

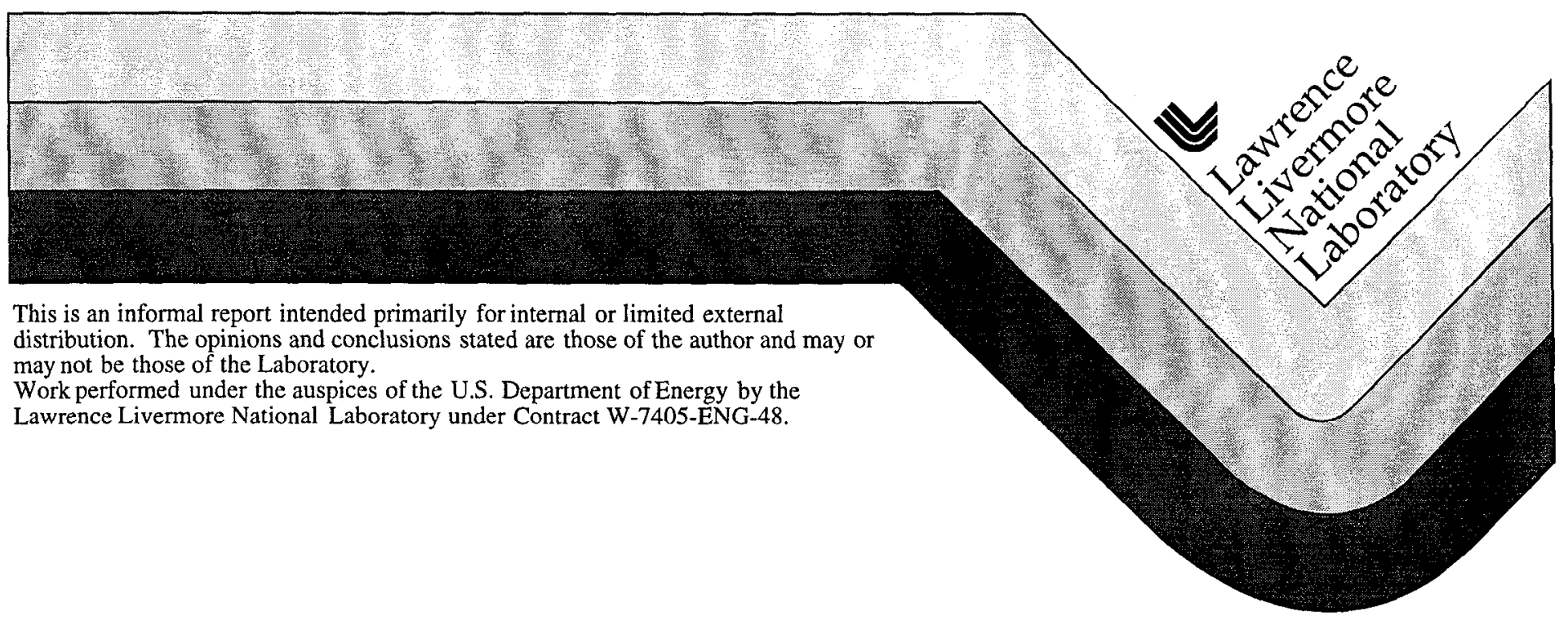




\section{DISCLAIMER}

This document was prepared as an account of work sponsored by an agency of the United States Government. Neither the United States Government nor the University of California nor any of their employees, makes any warranty, express or implied, or assumes any legal liability or responsibility for the accuracy, completeness, or usefulness of any information, apparatus, product, or process disclosed, or represents that its use would not infringe privately owned rights. Reference herein to any specific commercial product, process, or service by trade name, trademark, manufacturer, or otherwise, does not necessarily constitute or imply its endorsement, recommendation, or favoring by the United States Government or the University of California. The views and opinions of authors expressed herein do not necessarily state or reflect those of the United States Government or the University of California, and shall not be used for advertising or product endorsement purposes.

This report has been reproduced directly from the best available copy.

Available to DOE and DOE contractors from the Office of Scientific and Technical Information

P.O. Box 62, Oak Ridge, TN 37831

Prices available from (615) 576-8401, FTS 626-8401

Available to the public from the

National Technical Information Service

U.S. Department of Commerce

5285 Port Royal Rd.,

Springfield, VA 22161 
Summary of Analysis Results for Sediments Provided by Texas A\&M University

\author{
Cynthia Conrado, Steven Kreek \\ Analytical and Nuclear Chemistry Division \\ Lawrence Livermore National Laboratory
}

\begin{abstract}
DISCLAIMER
"This report was prepared by Lawrence Livermore National Laboratory as an account of work sponsored by GRI, DOE and API. Neither API, GRI, members of GRI, DOE, Lawrence Livermore National Laboratory, nor any person acting on behalf of them:

a. Makes any warranty or representation, express of implied, with respect to the accuracy, completeness, or usefulness of the information contained in this report, or that the use of information, apparatus, method or process disclosed in this report may not infringe on privately owned right; or

b. Assumes any liability with respect to the use of, or for damages resulting from the use of, any information, apparatus, method or process disclosed in this report."
\end{abstract}

Two soil samples were received by the Lawrence Livermore National Laboratory (LLNL) from Texas A\&M University (TA\&M) for the measurement of low-level ${ }^{226} \mathrm{Ra}$ and ${ }^{228} \mathrm{Ra}$. This effort was part of a project conducted by the American Petroleum Institute and Gas Research Institute to measure ${ }^{226} \mathrm{Ra}$ and ${ }^{228} \mathrm{Ra}$ in media relevant to offshore oil and gas operations.

The two samples were prepared for counting by packaging each in separate, highprecision, polycarbonate containers. The sample material was then compressed inside each container to minimize Rn migration, the sample weight determined, and a headspace-filling insert emplaced to occupy the vacant space above the sample and provide a tight seal against the top of the sample. The containers were then sealed and the samples set aside for 21 days to permit ${ }^{222} \mathrm{Rn}$ ingrowth. The use of the custom packaging yields counting samples with known cross-sectional area $\left(10.0 \mathrm{~cm}^{2}\right)$, density, and thickness. Table 1 shows the relevant sample preparation data for the two samples.

Table 1. Relevant sample information for the TA\&M samples.

\begin{tabular}{|c|c|c|c|c|}
\hline TA\&M ID & $\begin{array}{c}\text { Sample Weight } \\
(\mathrm{g})\end{array}$ & $\begin{array}{c}\text { Sample } \\
\text { Thickness }(\mathrm{cm})\end{array}$ & $\begin{array}{c}\text { Sample Density } \\
\left(\mathrm{g} / \mathrm{cm}^{3}\right)\end{array}$ & $\begin{array}{c}\text { Sample Area } \\
\left(\mathrm{cm}^{2}\right)\end{array}$ \\
\hline HS2-1 & 48.464 & 4.0 & 1.212 & 10 \\
\hline $262-1$ & 59.684 & 4.0 & 1.492 & 10 \\
\hline
\end{tabular}

After the 21-day ingrowth period, the samples were each counted by pulse-height analysis 5 times with 5 high-purity germanium (HPGe) detector systems in the Analytical and Nuclear Chemistry Counting Facility ${ }^{1}$ (NCCF) at LLNL. Each sample was counted for 5 days and the spectra collected over the energy range of about $50 \mathrm{keV}$ to about 2 $\mathrm{MeV}$ and the raw data stored in a central database for future analysis.

\footnotetext{
'. The NCCF is an extensive radiation measurement facility at LLNL and has capability to measure virtually any kind of radioactivity.
} 
The LLNL gamma-ray data interpretation program used to identify and quantify radionuclides measured by gamma-ray spectrometry is called GAMANAL. ${ }^{2}$ This code employs a geometric model (distance to sample, sample dimensions, etc.), and combines radiation transport physics with the sample specific information (thickness, density, average $Z$, etc.) and the intrinsic characteristics of each HPGe detector (intrinsic efficiency, active detector volume, Ge dead layer, pcak shape, resolution, ctc.) to determine the counting efficiency of each measurement. In addition to the specific information provided in Table 1, other sample parameters considered are the zero-time (September 11, 1997 for these samples) and composition of the container (for radiation attenuation correction, approximated as $0.12 \mathrm{~g} / \mathrm{cm}^{2} \mathrm{H}_{2} \mathrm{O}$ for the container used in this case). The method employed by LLNL is more robust than is generally found in a commercial analytical environment because GAMANAL does not require physical standards which approximate the samples in every way to perform an efficiency calibration. LLNL uses this method because many situations do not lend themselves to the creation of standards which nearly duplicate the samples of interest. Instead, LLNL calibrates against NIST traceable point sources and determines the intrinsic efficiency of each HPGe detector. The use of the intrinsic characteristics of the HPGe detector and a geometric model reduces the frequency with which the detector systems must be calibrated.

The data interpretation process is performed by the code GAMANAL. This code reads the spectral data, determines the background, locates the peak regions, determines the gamma-ray energies and intensities, corrects the measured gamma-ray intensities for attenuation (sample and container), selects all likely component nuclides, performs a least-squares matrix inversion calculation for each set of possible interferences, and computes the final activity present per unit weight of sample. Because each sample was counted on five different detectors, the weighted average and standard deviation was calculated for each isotope identified from the 5 independent measurements. Table 2 presents the weighted averages of the isotopes reported in the samples, HS2-1 and 262-1. The error-weighted averages were calculated using the method described in the Nuclear Data Tables. As can be interpreted from the reported uncertainties in Table 2, these samples contain an easily detectable quantity of the relevant radionuclides.

Iable 2. Radium concentration in picoCuries ( $\mathrm{pCi} / \mathrm{g}$ ) sample material. Note that the samples were not dried extensively prior to measurement. Errors are 1 sigma.

\begin{tabular}{|l|l|l|}
\hline Sample ID & $\begin{array}{l}{ }^{226} \mathrm{Ra} \text { concentration } \\
(\mathrm{pCi} / \mathrm{g})\end{array}$ & $\begin{array}{l}{ }^{228} \mathrm{Ra} \text { concentration } \\
(\mathrm{pCi} / \mathrm{g})\end{array}$ \\
\hline HS2-1 & $0.79 \pm 0.90 \%$ & $1.22 \pm 1.1 \%$ \\
\hline $262-1$ & $0.91 \pm 0.76 \%$ & $1.09 \pm 1.1 \%$ \\
\hline
\end{tabular}

\footnotetext{
${ }^{2}$ J. B. Niday and R. Gunnink, "A Gamma-Ray Spectral Interpretation Code, GAMANAI, "Lawrence Livermore National Laboratory Report Number, UCRL-51061, 1972.
} 